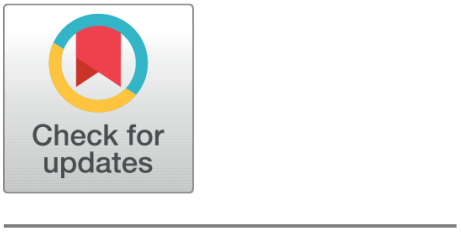

OPEN ACCESS

Received: 18.11 .2020

Accepted: 20.12 .2020

Published: 21.01 .2021

Citation: Agrawal S, Sharma C, Dinesh Birla (2021) Enhanced PLL (EPLL) Synchronization and HBCC Controlling of Grid-Interactive (PV-SOFC) Hybrid Generating System. Indian Journal of Science and Technology 14(2): 154-169. http s://doi.org/10.17485/IJST/v14i2.2079

* Corresponding author.

seema10dec@gmail.com

Funding: None

Competing Interests: None

Copyright: $(2021$ Agrawal et al. This is an open access article distributed under the terms of the Creative Commons Attribution License, which permits unrestricted use, distribution, and reproduction in any medium, provided the original author and source are credited.

Published By Indian Society for Education and Environment (iSee)

ISSN

Print: 0974-6846

Electronic: 0974-5645

\section{Enhanced PLL (EPLL) Synchronization and HBCC Controlling of Grid-Interactive (PV-SOFC) Hybrid Generating System}

\author{
Seema Agrawal ${ }^{1 *}$, Chavi Sharma ${ }^{1}$, Dinesh Birla ${ }^{1}$ \\ 1 Department of Electrical Engineering, Rajasthan Technical University, Kota, 324010, India
}

\section{Abstract}

Objective: In a grid-interactive (PV-SOFC) generation system, the inverter is the main constituent. Further, the quality of the injected signal in utility depends upon inverter control and synchronization. Thus, the main objective of this paper is to control the single-phase inverter for a hybrid DC generation system and obtain synchronization between the grid signal and hybrid renewable energy source (RES) inverted output signal. Methods/Statistical analysis: This paper suggests software modeling of the grid-interactive hybrid photovoltaic array (PV) and solid oxide fuel cell (SOFC) power generation system to supply continue load demand. The enhanced phase locked loop (EPLL), and hysteresis band current controller (HBCC) utilize to control single-phase inverter for hybrid generation system. The main benefit of EPLL configuration beyond traditional PLL's is to compose and keep up phase change zero between input and output of voltage controlled oscillator (VCO). So, the EPLL tracks the phase angle and amplitude of the signal. The incremental conductance based MPPT technique is implemented in the proposed architecture to enhance the system's efficiency by maximizing extracted power from the PV configuration. In addition, the synchronization between the grid signal and hybrid RES inverted output signal is obtained with EPLL. The simulation results with system design parameters are carried out in MATLAB 2015. Findings: The efficacy of the proposed synchronization circuit of EPLL is confirmed through the compensation of twice time-frequency error, which is introduced in traditional PLL. Further, from the simulation results, it is observed that smooth frequency is obtained with the proposed EPLL. Moreover, the performance index parameter (\%THD) of current in the presence of EPLL and HBCC is smaller than the traditional PLL. Novelty: This paper introduces a hybrid EPLL and HBCC approach to control the single-phase inverter for a hybrid PV-SOFC generation system.

Keywords: Photovoltaic array (PV); incremental conductance based maximum power point tracking (INC-MPPT); synchronization; solid oxide fuel cell (SOFC); hysteresis band current controller; enhanced phase locked loop (EPLL); grid 


\section{Introduction}

The penetration of renewable energy sources (RESs) has been continuously increased in the modern power system. These RESs are environmentally friendly but provide an unpredicted generation. Besides, various RESs are highlighted in the literature, such as solar, wind, hydro, tidal, biomass, geothermal, and wave ${ }^{(1,2)}$. Most of the researches are available on solar power applications ${ }^{(3)}$. Further, the solar panel's efficiency has improved using the maximum power point tracking (MPPT) approaches. In the literature, various MPPT approaches have been introduced, such as the traditional hill-climbing, incremental conductance (IC), fractional open-circuit voltage, and fractional shore circuit current ${ }^{(4,5)}$. However, the IC algorithm gives better performance under rapid environmental variations. Hence, in this paper, we use this IC-MPPT approach in the generation system to extract power from the photovoltaic array (PV).

In the literature, solid oxide fuel cell (SOFC) is interconnected in a parallel manner with the PV to ensure the continuity of power supply and handle load demand in the absence of solar energy. SOFC is a green source of energy because it only produces water as a byproduct. Further, SOFC has many advantages over traditional energy conversion systems, such as reliability, good competence, modularity, and fuel adaptability ${ }^{(6-8)}$. This paper is easy to use photovoltaic (PV) along with SOFC to meet erratic loads for either grid or standalone applications.

The main limitation of the RESs is about maintaining the constant power quality and about synchronizing between the discrete energy sources and micro-grids. In the present literature, a phase-locked loop (PLL) based synchronization method is widely utilized ${ }^{(9-11)}$. Further, the enhanced PLL (EPLL) is applied to extract fundamental frequency. An EPLL has the same assembly as the PLL. The main variation between PLL and EPLL is that phase change among input and VCO output is invariable in PLL and maintain zero in EPLL ${ }^{(12)}$. Unit vector sine- cosine creation is done using EPLL to eliminate the synchronization delay due to PLL.

Grid synchronization and power quality control of power injected into the grid is a significant factor. So with the help of the current control loop, an inverter designs as a high power factor and also, has no problem in grid integrated operation. The operation of the inverter has a dependency on utilized current control methods. So, numerous linear and non-linear current control techniques have been discussed in the literature. Linear control techniques are the proportional-integral, proportional resonant, and repetitive controller. Besides, the non-linear current control methods such as dead beat, predictive hysteresis band current control have been illustrated in literature ${ }^{(13-17)}$. Amongst these current control methods, the hysteresis band current controller (HBCC) is one of the best choices as a voltage source inverter control method due to simple implementation, robustness, inbuilt limit, and good transient response ${ }^{(18)}$.

Due to irregular solar nature, the SOFC will offer support to solar power production, and it is decreased the effect of irregularities. For this purpose, the coordinated action of (PV-SOFC) can expand the reliability of the RESs to the clients ${ }^{(19-21)}$. These sources grant DC power, which must be inverted into AC supply for AC loads run. This conversion is completed by PWM inverters, which are controlled by HBCC and synchronized with the grid using EPLL. Further, the hybrid generated inverted AC output integrates with the grid.

\section{Hybrid generation system architecture}

Figure 1 shows the suggested system architecture, which consists of a hybrid generation system (PV-SOFC). The INC MPPT algorithm is designed to maximize extracted power from the PV system. Further, the voltage source inverter (VSI) current is controlled by the HBCC. Hybrid generation system after inversion by the inverter is interconnected with the grid. Inverted output current is synchronized with the grid using EPLL. Generated reference current via EPLL and inverted output current are compared in HBCC to generate proper gate signal for VSI inverter. 


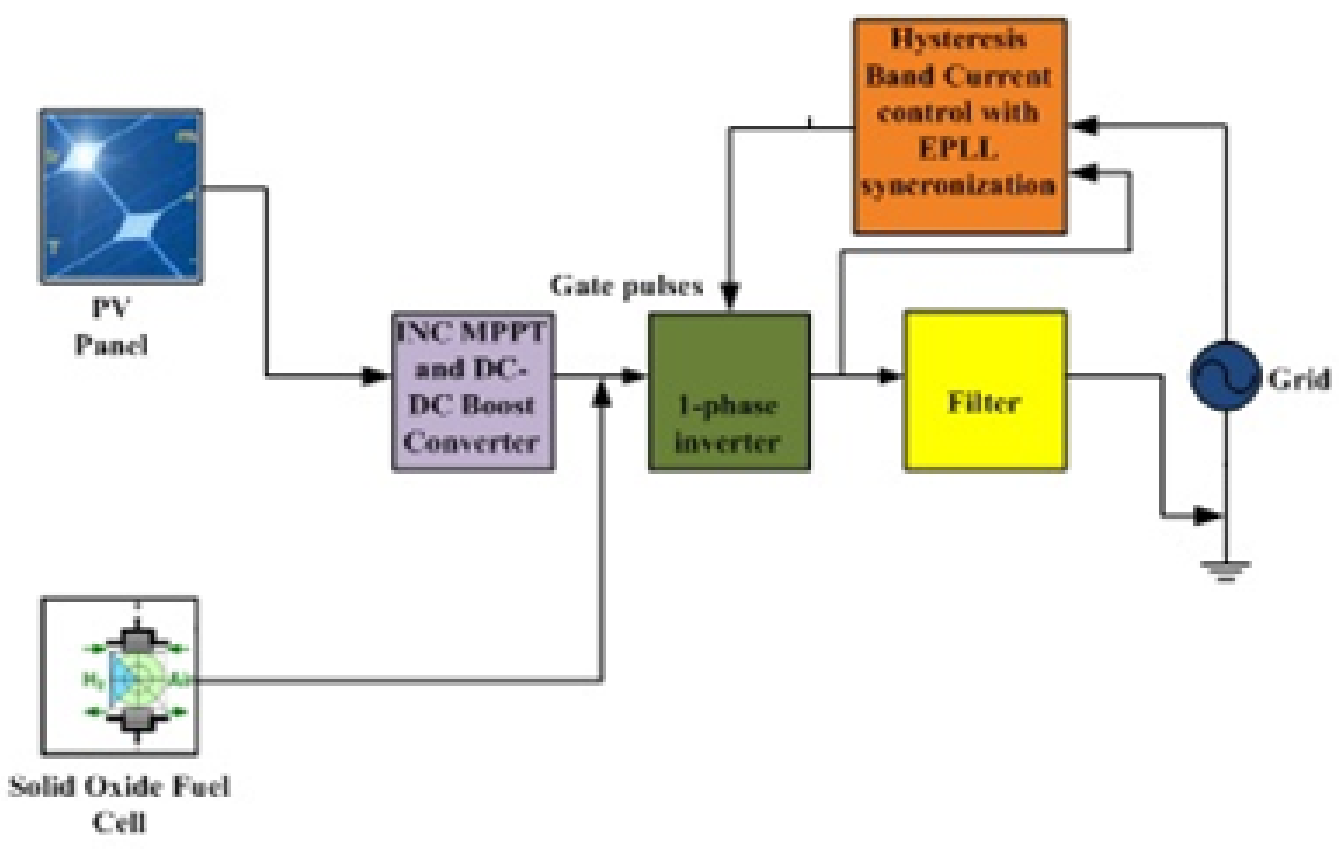

Fig 1. Suggested system architecture

\subsection{PV generation system with MPPT controller}

The phovoltaic cell is illustrated in Figure 2. Series parallel combination of the cells are developed a PV module. Besides, the series parallel assembling of module generates the PV panel to get the desired signal level of PV voltage and current.

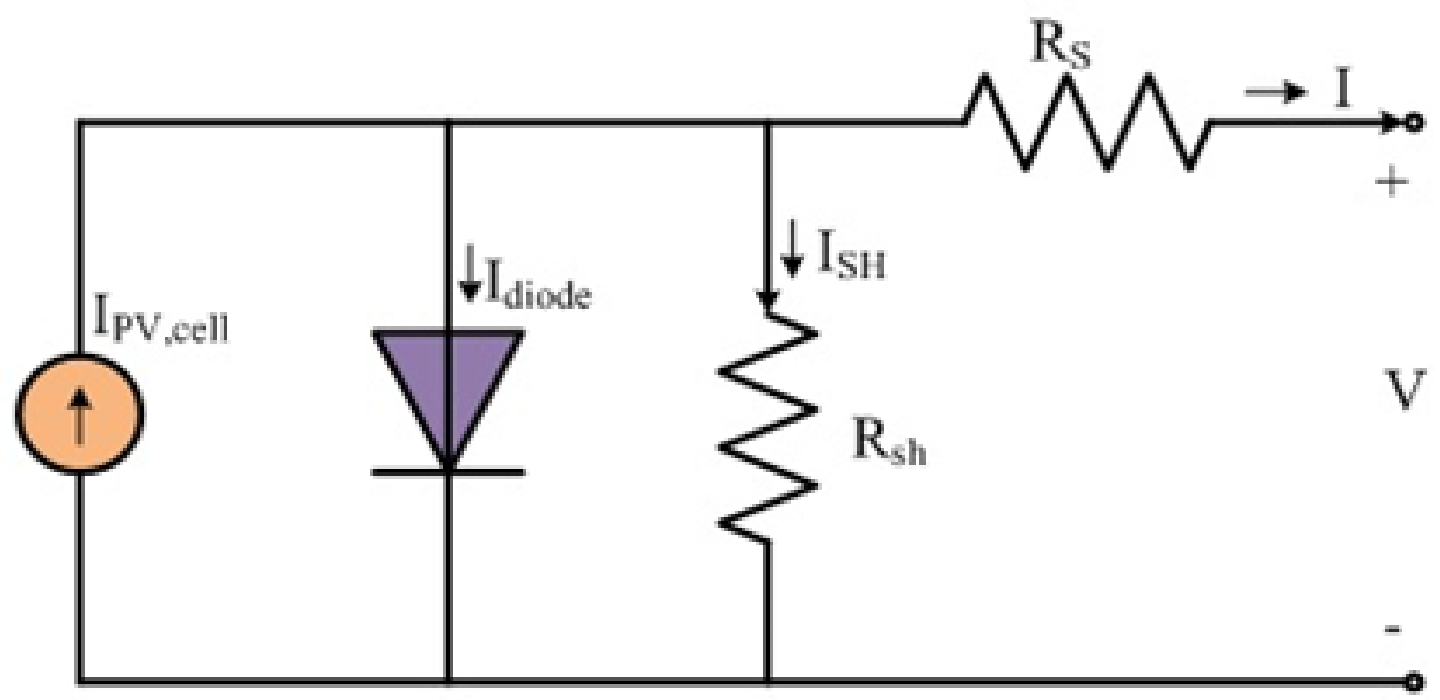

Fig 2. PV cell Block.

For an ideal PV array, solar cell current is defined as follows

$$
I_{o}=I_{P V, \text { cell }}-I_{\text {dode }}
$$




$$
I_{0}=I_{P V, \text { cell }}-I_{\text {rev }, \text { cen }}\left[\exp \left(\frac{q V}{\alpha K T}\right)-1\right]
$$

Where,

$\mathrm{I}_{0}$ is the cell current

$\mathrm{I}_{P V, \text { cell }}$ is the light photo current

$\mathrm{I}_{\text {rev, cell }}$ is the cell saturation current

$\mathrm{K}$ is the Boltzmann constant $\left(13806503^{\star} 10-23 \mathrm{~J} / \mathrm{K}\right)$

$\mathrm{T}$ is the PN junction temp.

$\mathrm{V}$ is the Output voltage

$\mathrm{q}$ is the Charge of electron

In the case of practical PV array cell current formulation is required some extra parameter consideration, so it is given as follows

$$
\begin{gathered}
I_{o}=I_{P V, \text { cell }}-I_{\text {diode }}-I_{S H} \\
I=I_{P V, \text { cell }}-I_{\text {rev }, \text { cell }}\left[\exp \left(\frac{V+I R_{s}}{\eta V_{T}}\right)-1\right]-\frac{V+I R_{s}}{R_{s h}}
\end{gathered}
$$

Where,

$\mathrm{R}_{S}, \mathrm{R}_{s h}$, and $\mathrm{V}$ are equivalent series and parallel resistance and the terminal voltage of PV array, respectively.

Extract maximum power from the solar panel and efficiency enhancement is a critical issue in photovoltaic cell power generation. This involves current measurements and voltage to determine load impedance and performance that best matches the cell's basic impedance. Determine an argument on the I-V curve of the solar cell by maximum power point tracking system as shown graphically in Figure 4 .

To achieve the maximum power, the duty cycle of the switch is controlled by an INC algorithm, which is illustrated in Figure 3

Power equation can be written as

$$
P=V I
$$

Chain law application for product derivative

$$
\frac{\partial P}{\partial V}=\frac{[\partial(V I)]}{\partial V}
$$

At maximum power point,

$$
\frac{\partial P}{\partial V}=0
$$

Equations in terms of array voltage and array current $\mathrm{V}$ and $\mathrm{I}$ is given as

$$
\frac{\partial I}{\partial V}=-\frac{I}{V}
$$

Applied incremental conductance technique generates gating pulse for DC-DC boost converter until maximum power point condition $\{(\partial / \partial V)+(I / V)=0\}$ is satisfied. IC algorithm is represented in Figure 3, and the power output curve is depicted in Figure 4. 


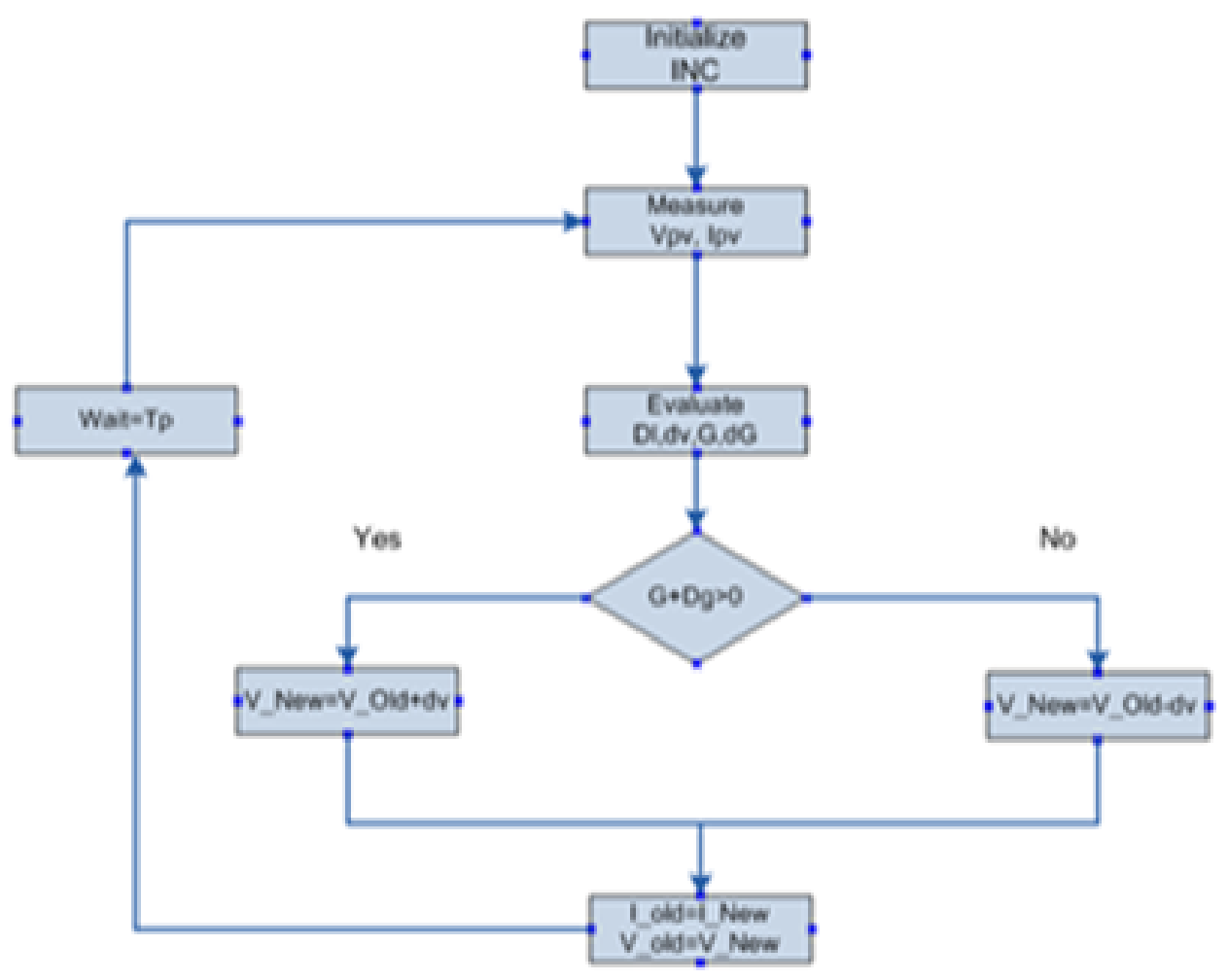

Fig 3. Flowchart of INC algorithm

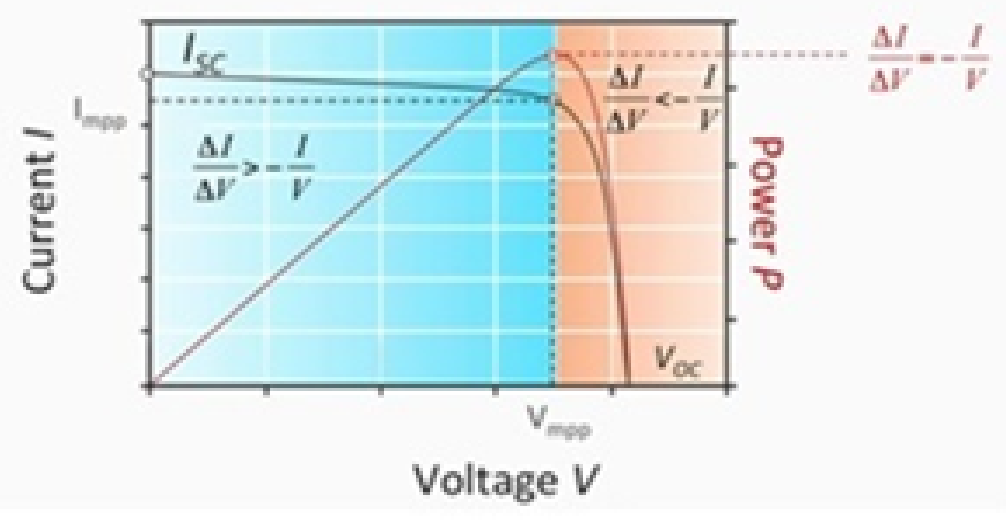

Fig 4. Graphical representation of MPPT

\subsection{SOFC mathematical modeling}

The power is produced through the process of electrochemical conversion. The electricity is obtained directly by fuel oxidization. Solid oxide fuel cell (SOFC) MATLAB Simulink model based on Nernst equations is described in Figure 6 .

Pressure flow of hydrogen, hydrogen oxide and oxygen $\left(\mathrm{P}_{-} \mathrm{H}_{2}, \mathrm{P}_{-} \mathrm{H}_{2} \mathrm{O}\right.$, and $\left.\mathrm{P}_{-} \mathrm{O}_{2}\right)$ can be seen in Figure 5 . 


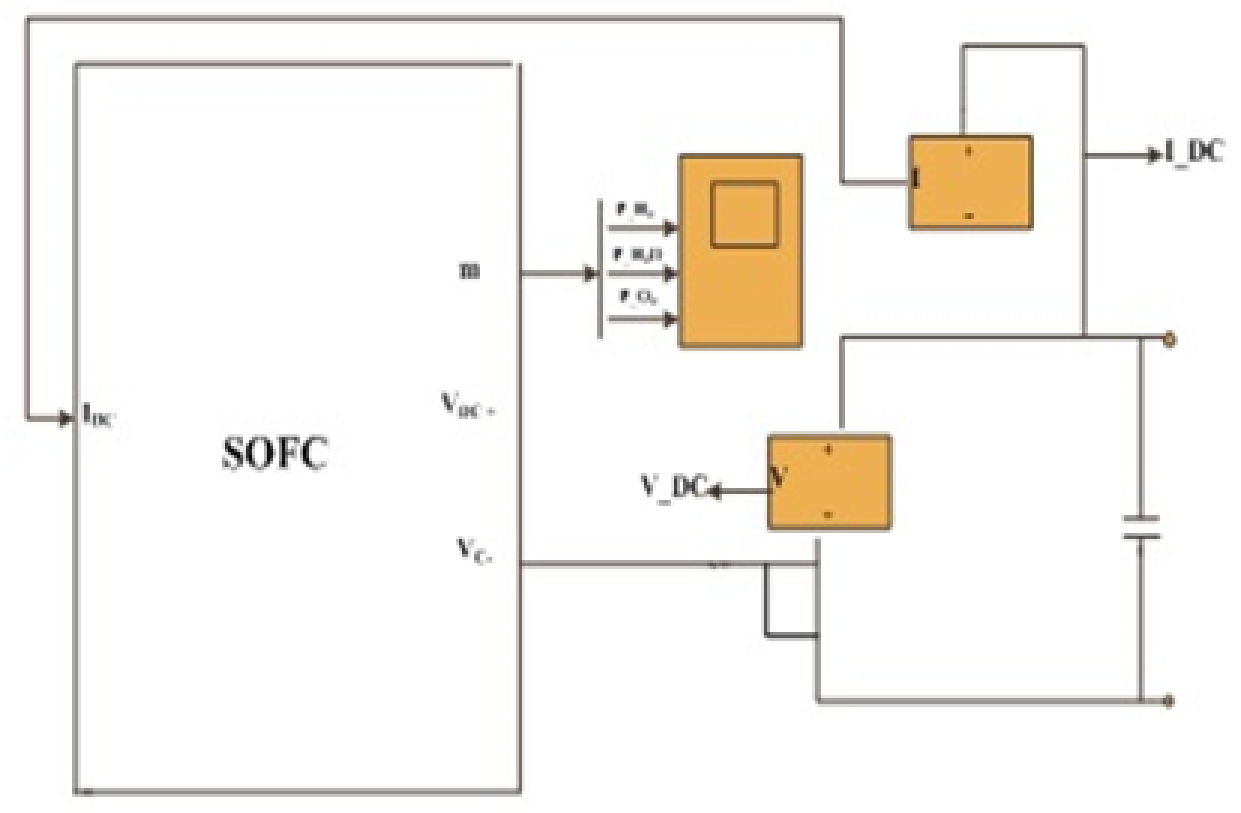

Fig 5. SOFC block diagram

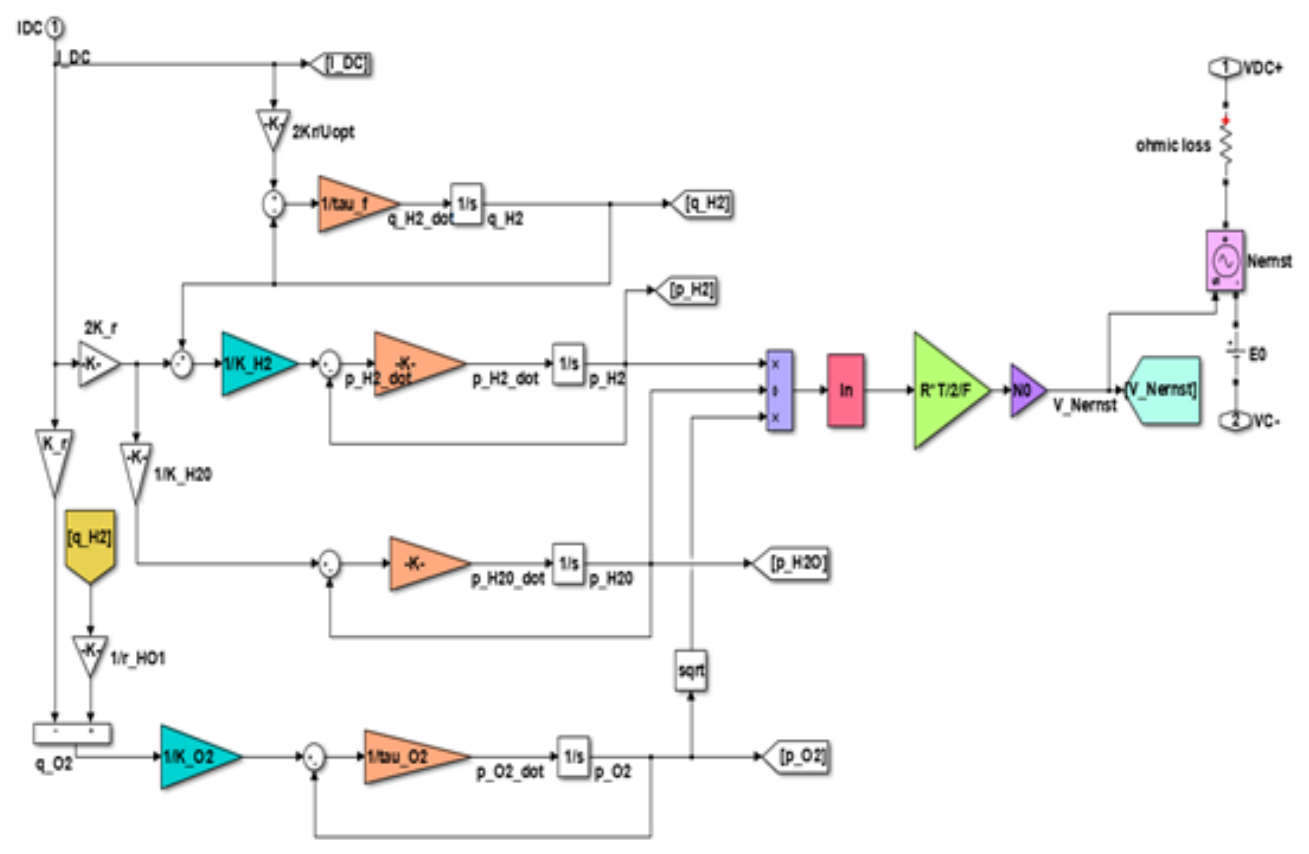

Fig 6. Nernst equations based internal SOFC Simulink diagram 


\section{Inverter current control and synchronization with grid}

HBCC is used to control the VSI inverter. The synchronization with the grid is done by EPLL.

\subsection{EPLL synchronization}

The EPLL is a negative feedback closed-loop system, which is shown in Figure 7 . The main input signal and the output signal of VCO is applied to the two inputs of the phase detector. The phase difference among input and VCO output can be done and maintained zero in EPLL.

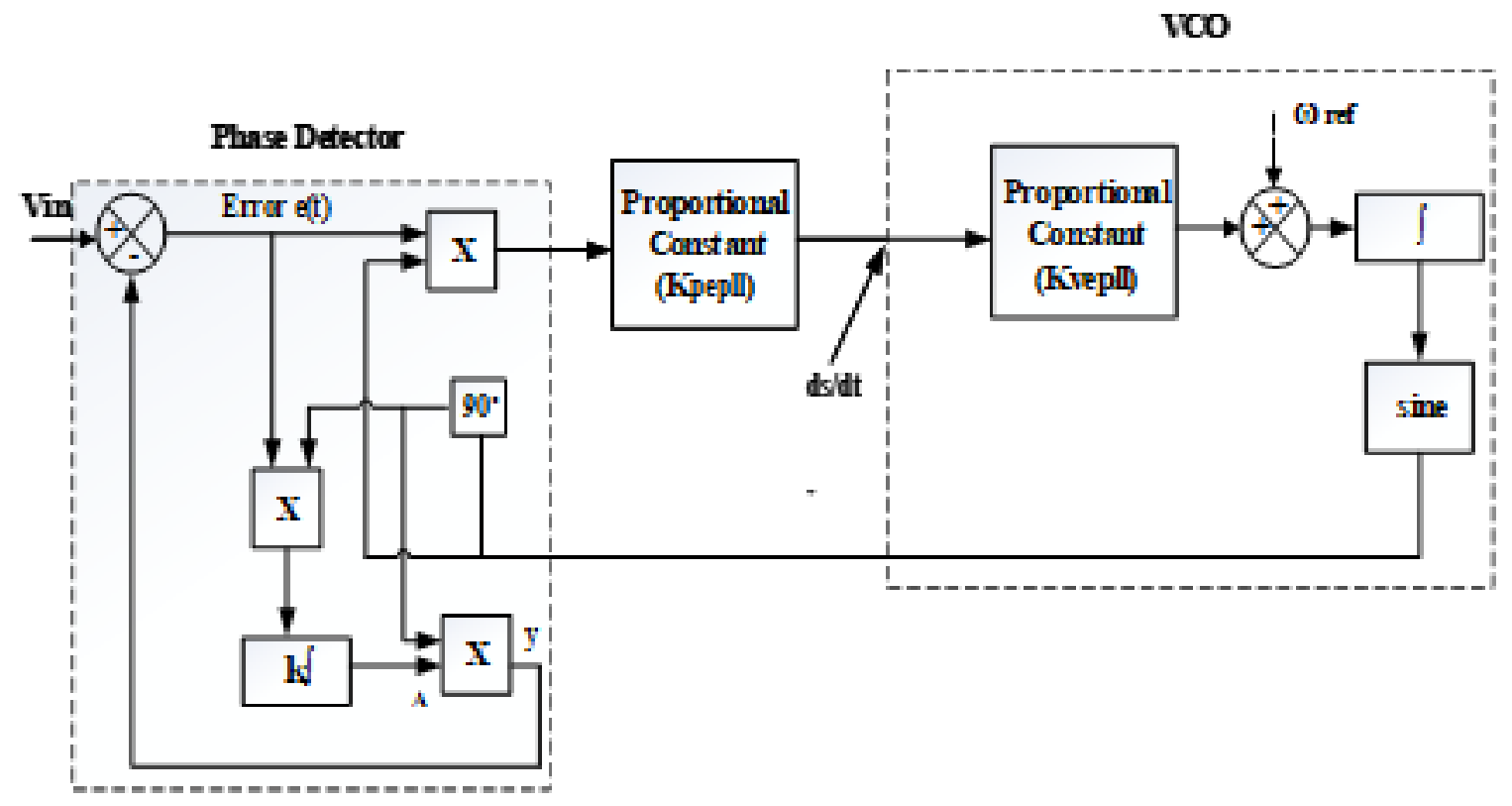

Fig 7. Building block diagram of an enhanced phase-locked loop (EPLL)

If $\operatorname{vin}(t), \operatorname{vout}(t)$ are $\mathrm{i} / \mathrm{p}$ and $\mathrm{o} / \mathrm{p}$ voltage signal of EPLL respectively. $e(t)$ (error) is shown mathematically as

$$
\begin{gathered}
e(t)=v_{\text {in }}(t)-v_{\text {out }}(t) \\
v_{\text {in }}(t)=v \sin (\omega t+\varphi) \\
v_{\text {out }}(t)=v \sin (\omega t+\varphi)
\end{gathered}
$$

The error signal is a function of amplitude, radial frequency, and phase angle ( $v, \omega, \phi)$, respectively. It is illustrated by the following equation.

$$
E(v, \omega, \varphi)=\left\|v_{\text {in }}(t)-v_{\text {out }}(t)\right\|^{2}
$$

Three multiplications $\left(^{*}\right)$, one integration $(\bigotimes)$, and one subtraction $(-)$ are needed in enhanced PLL. It is tracked phase as well as amplitude and provides output signal fully synchronous with input. Robustness is shown concerning deviation its internal constraints such as (K, $\left.\mathrm{K}_{\text {pepll }}, \mathrm{K}_{\text {vepll }}\right)$ and central frequency $\left(\mathrm{VCO}\right.$ 's) $\omega_{\text {ref }}(\mathrm{rad} / \mathrm{sec})$.

EPLL synchronizing output sine unit vector is described as;

$$
U_{s}=\sin (\omega t)
$$




\subsection{Hysteresis band current controller (HBCC)}

In the case of the hysteresis band, switching signals are generated for the inverter to control load current. Appropriate stability, quick response, high accuracy, easy operation, inbuilt peak current limitation, and load parameter variations make hysteresis current control one of the better voltage source inverter control methods. As shown in Figure 9, SW1, SW2, SW3, and SW4 are the VSI switching states generated by the hysteresis comparator.

The output of the comparator is turned on when the load current rises beyond the upper band limit to change output voltage so that the load current is decreased and kept between bands and disconnected at a lower limit, as shown in Figure 8 .

Switching frequency varies from the upper band (UB) to the lower band (LB). Other design parameters such as inverternetwork inductance and DC link voltage disturb switching frequency significantly. Inverter control is possible in the unipolar or bipolar PWM method. In this method, the current error, which is the difference between reference and inverter currents, is controlled in the hypothetical control band surrounding the reference current.

Switch on/off condition is defined as follows:

$$
S W=\left\{\begin{array}{ll}
0 \rightarrow \text { if } & \left.I_{\text {acthal }}(t)\right\rangle\left(I_{\text {ref }}(t)+H B\right) \\
1 \rightarrow \text { if } & I_{\text {actial }}(t)\left\langle\left(I_{\text {ref }}(t)-H B\right)\right.
\end{array}\right\}
$$

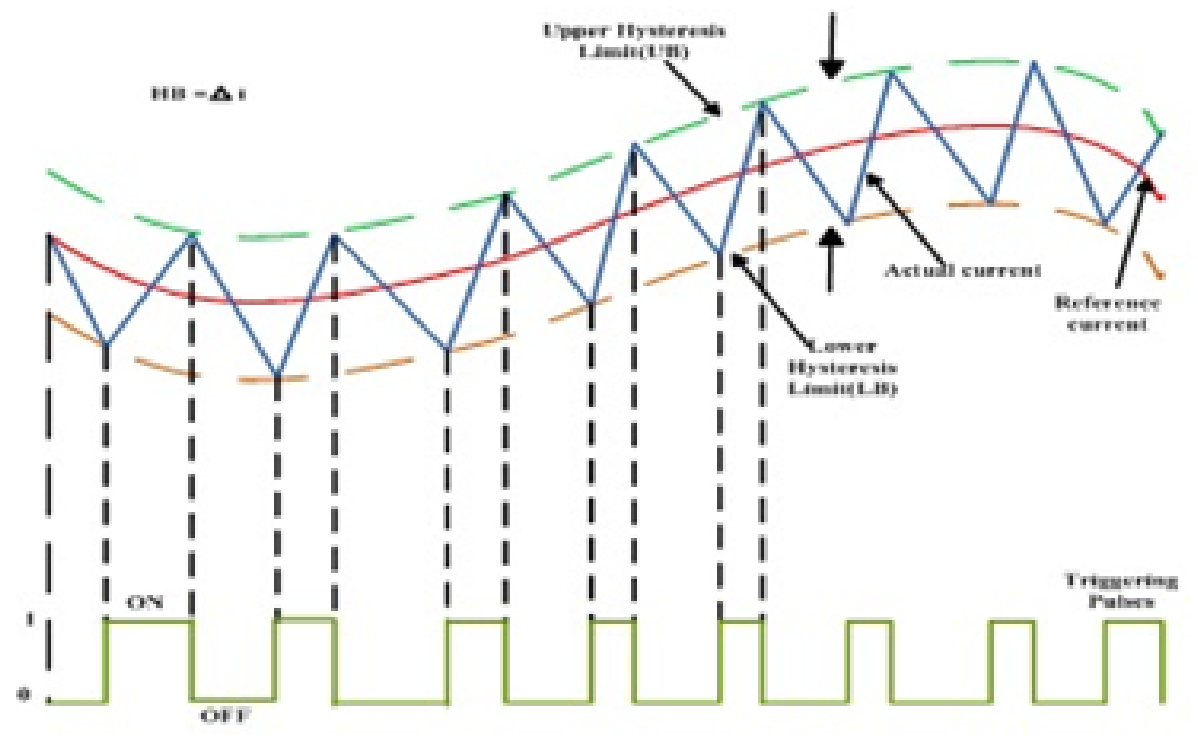

Fig 8. The operational waveform of the hysteresis band current controller

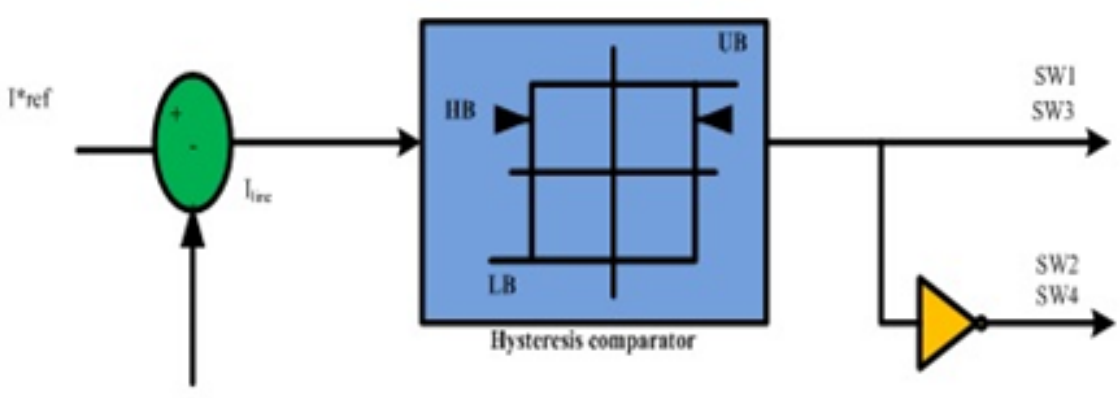

Fig 9. Block diagram representation of the hysteresis band current controller 


\section{Simulation model and result}

The proposed system design is explained in Figure 10 . Simulated design parameters are listed in Table 1 . Four panels are connected in parallel. Each panel has 38 cells with quality factor 2 . Another specification is enclosed in Table 1.

Table 1. Simulation parameters

\begin{tabular}{ll}
\hline System & Parameters /values \\
\hline \multirow{3}{*}{ PV system specification } & Short circuit current per cell( Isc $)=1.9 \mathrm{~A}$ \\
& Open Circuit Voltage per cell $(\mathrm{Voc})=1.17 \mathrm{~V}$ \\
& Series resistance $(\mathrm{Rs})=0.02 \mathrm{ohm}$ \\
\hline & Absolute temperature $(\mathrm{K})=1273$ \\
& Faraday Constant $(\mathrm{C} / \mathrm{kmol}))=96.487^{\star} 10^{6}$ \\
& Initial Current $(\mathrm{A})=100$ \\
& Universal gas constant $\mathrm{J} /(\mathrm{kmol} \mathrm{K})=8314$ \\
& Ideal standard potential $(\mathrm{V})=1.18$ \\
& Number of cells in series $=360$ \\
& Maximum, minimal and optimal fuel utilization $=[0.90 .80 .85]$ \\
SOFC specification & Valve molar constant for hydrogen, water and oxygen $(\mathrm{kmol} /(\mathrm{s}$ atm $)=[8.43 \mathrm{e}-4,2.81 \mathrm{e}-4$, \\
& $2.52 \mathrm{e}-3]$ \\
& Response time for hydrogen, water and oxygen flow $(\mathrm{s})=[26.1,78.3,2.91]$ \\
& Electrical response time $=.8$ \\
& Hydrogen to oxygen Ratio $=1,145$ \\
& Ohmic loss per cell $=3.2813 \mathrm{e}-004$ \\
\hline Inverter and filter parameters & Shunt filter $\mathrm{R}_{f}=1 \mathrm{~m} \Omega, \mathrm{C} f=10 \mu \mathrm{F}$ \\
& Series inductor $\mathrm{L}_{s}=12 \mathrm{mH}, \mathrm{R}_{s}=.001 \Omega$ \\
& IGBT/diode 2 arm $\mathrm{Snubber}$ resistance $=10^{5} \Omega$ \\
\hline
\end{tabular}

Irradiation change from $1000 \mathrm{~W} / \mathrm{m}^{2}$ to $500 \mathrm{~W} / \mathrm{m}^{2}$, which is shown in Figure 11 . The simulated response of the PV array before the application of the MPPT controller is analyzed. The PV array voltage is changed from $84.3 \mathrm{~V}$ to $82.5 \mathrm{~V}$ as shown in Figure 12, respectively, but PV panel output voltage after applying INC MPPT controller boosted voltage does not change with irradiation be constant at $340 \mathrm{~V}$, as shown in Figure 13 .

SOFC generated signals are illustrated in Figure 15. SOFC pressure graph is also described in Figure 14. The VSI inverter output voltage is depicted in Figure 16, which is a non-sinusoidal signal. After applying the filter, it is converted into a sine signal with an approximate zero total harmonic distortion factor, as examined from Figure 23.

Filtered voltage is perfectly synchronized with grid voltage, as shown in Figures 17 and 18 . EPLL tracked frequency is illustrated in Figure 21 . It is held value $50 \mathrm{~Hz}$ as the fundamental frequency of the grid. It shows perfect tracking of frequency by EPLL. Phase and unit reference sin vector are tracked by EPLL are examined in Figures 20 and 19 , respectively. Precise inverter current control by HBCC with EPLL can be seen in Figure 22 . In this inverter, the current proceeds as grid current. We can examine \% THD of inverter output current with PLL $(2.51 \%)$ and EPLL $(0.88 \%)$ in the harmonic spectrum graph, as shown in Figures 24 and 25 . A comparative graph (which is shown in Figure 26 ) shows that EPLL synchronization has more efficacy than conventional PLL.

Several authors reported 2 3\% of THD with synchronization of PLL with the grid. In this paper, a novel EPLL has been proposed. After synchronization of EPLL with grid, $0.88 \%$ of THD has been evident, which proves its feasibility with the grid compared to traditional PLL. 


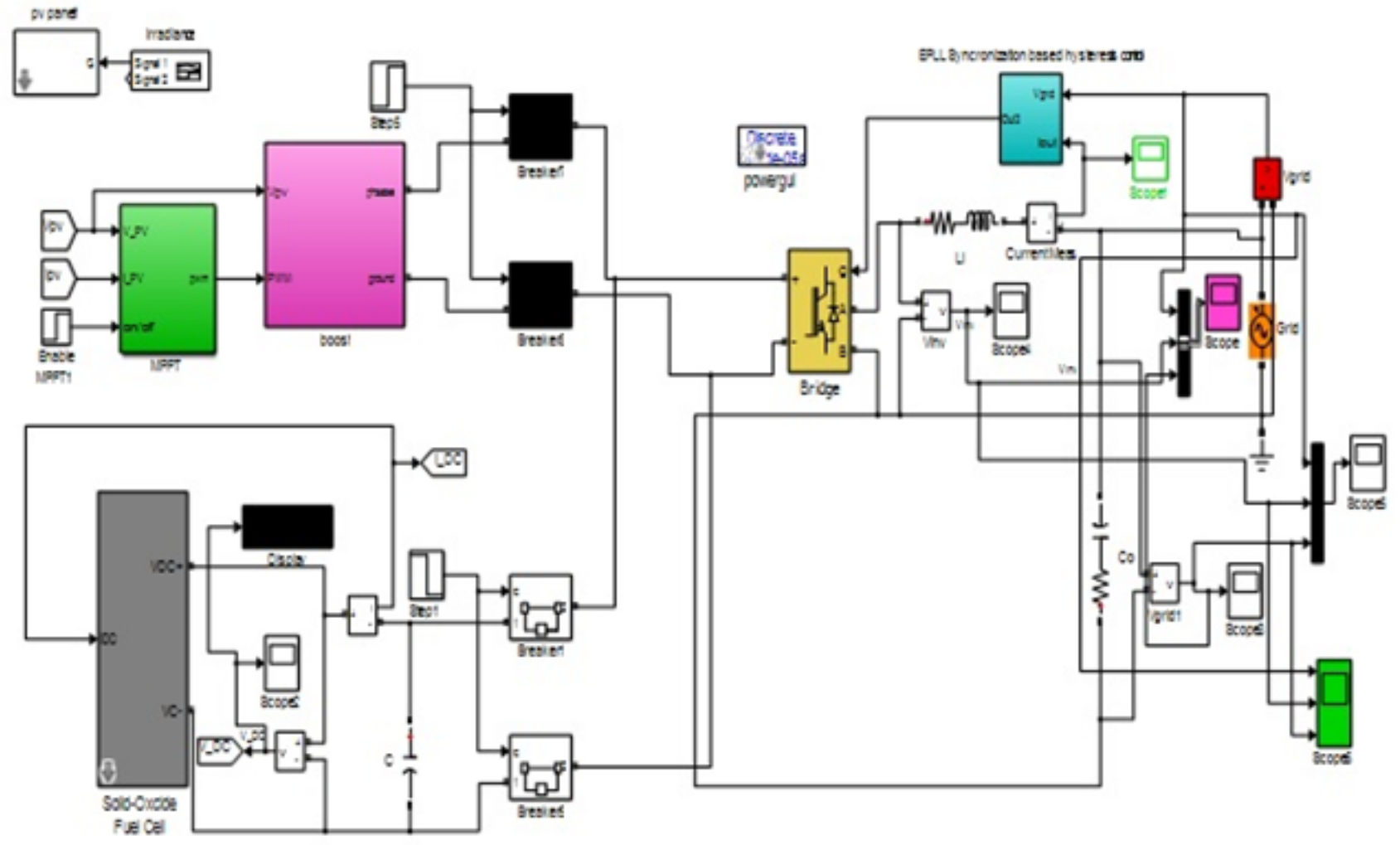

Fig 10. Simulink design of proposed architecture

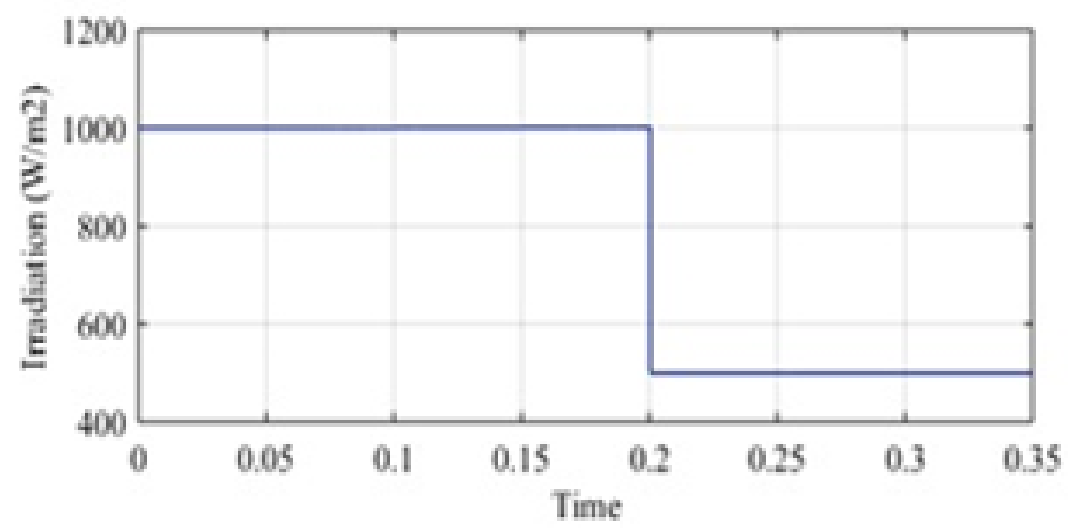

Fig 11. Solar irradiations 


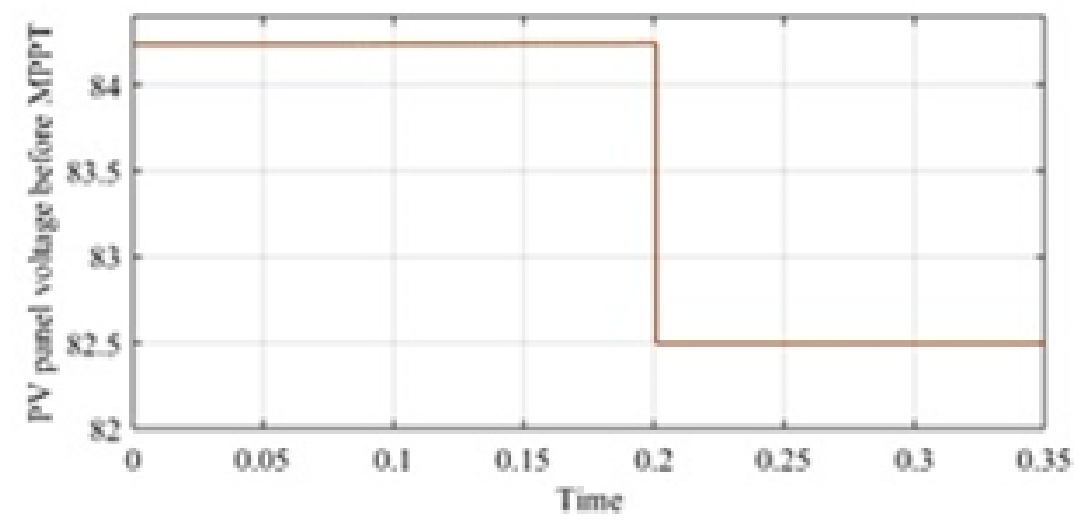

Fig 12. PV panel output voltage before MPPT with irradiation variation

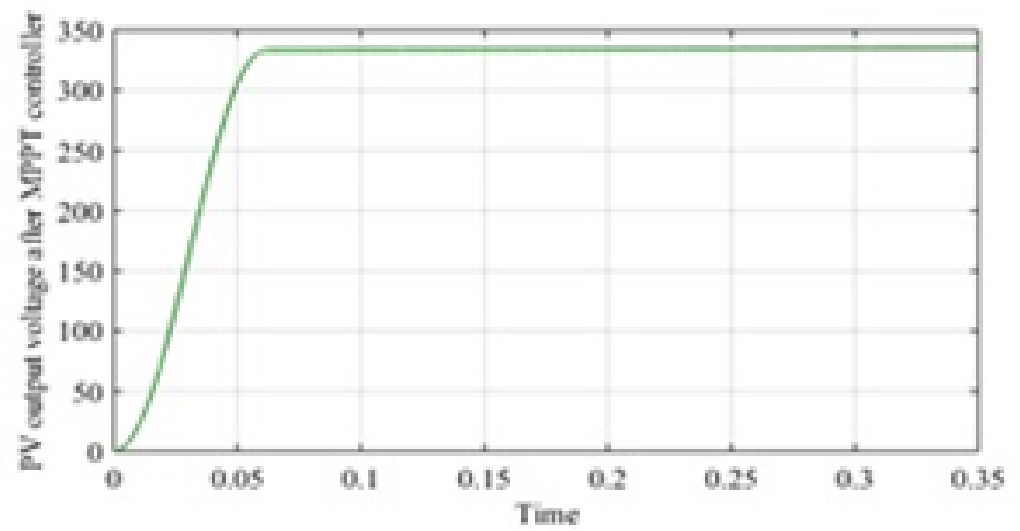

Fig 13. Boosted PV panel waveform

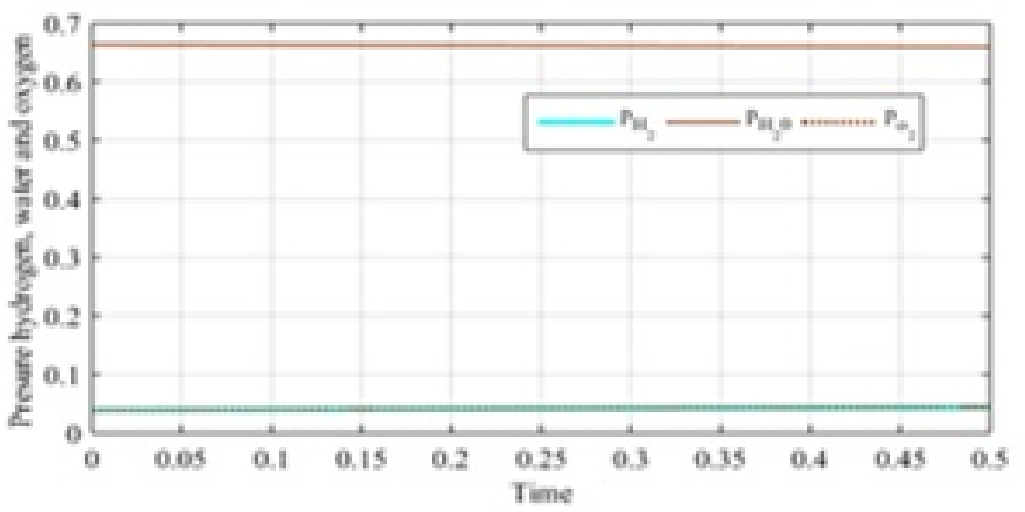

Fig 14. The pressure of $\mathrm{H}_{2}, \mathrm{H}_{2} \mathrm{O}$, and $\mathrm{O}_{2}$ in SOFC 


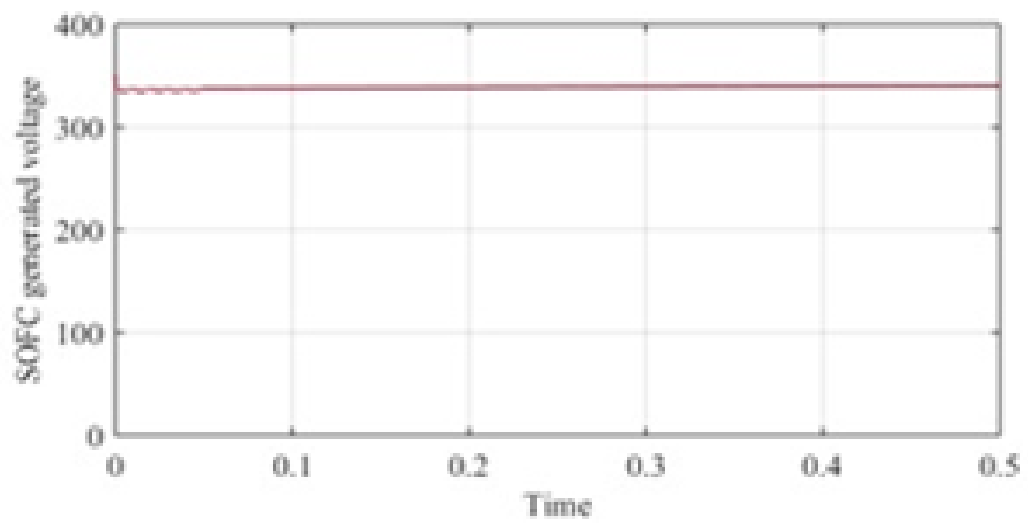

Fig 15. SOFC output voltage

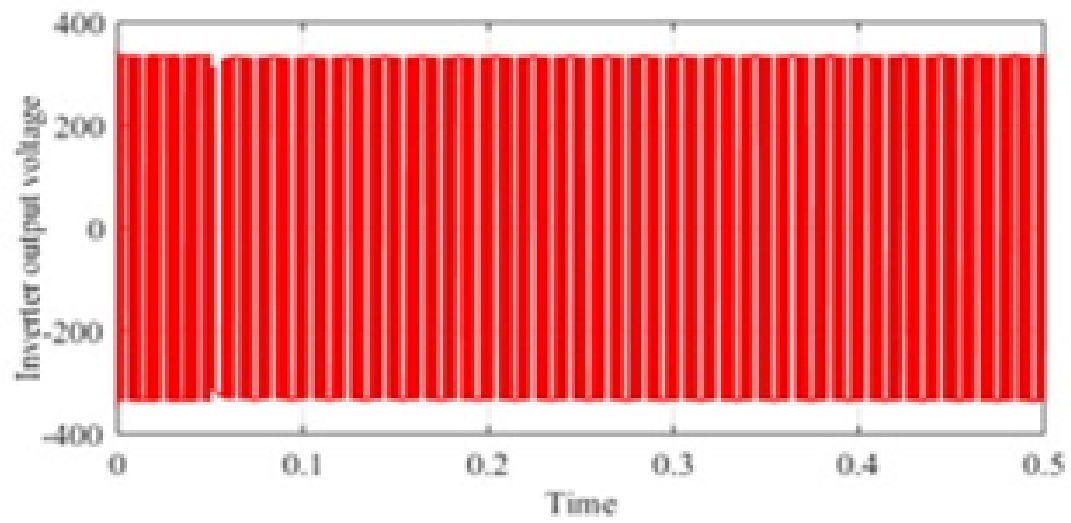

Fig 16. VSI inverter output voltage waveform

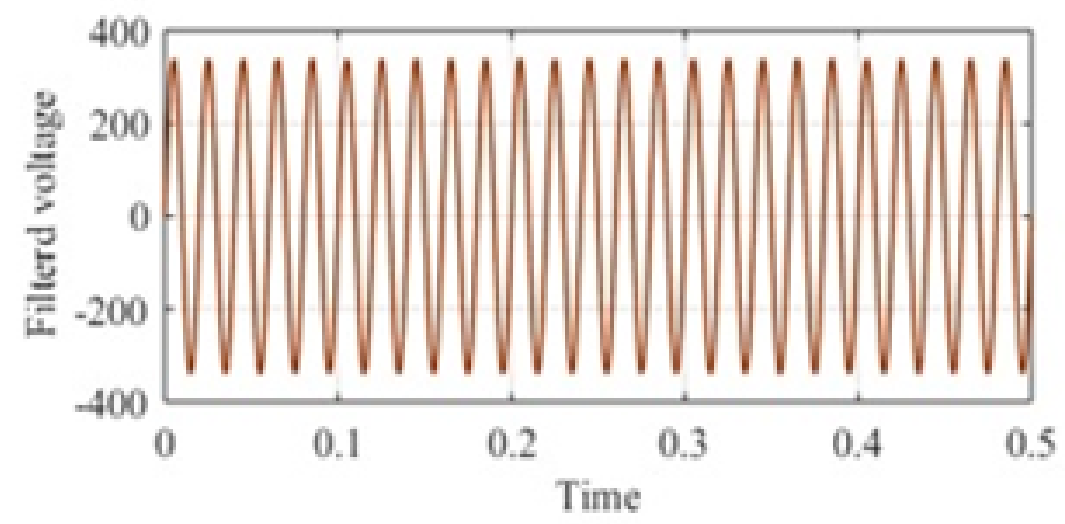

Fig 17. Filtered voltage waveform 


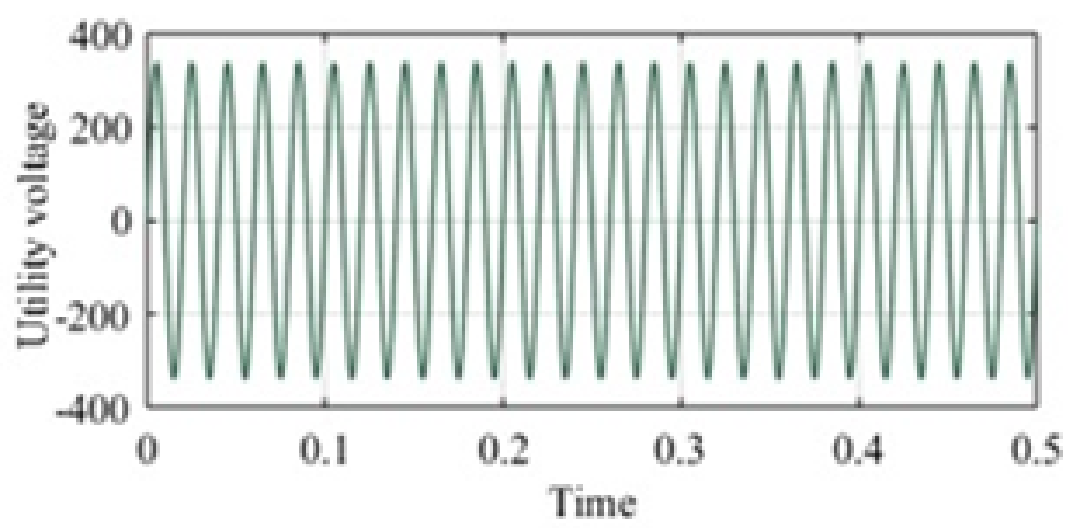

Fig 18. Utility voltage waveform

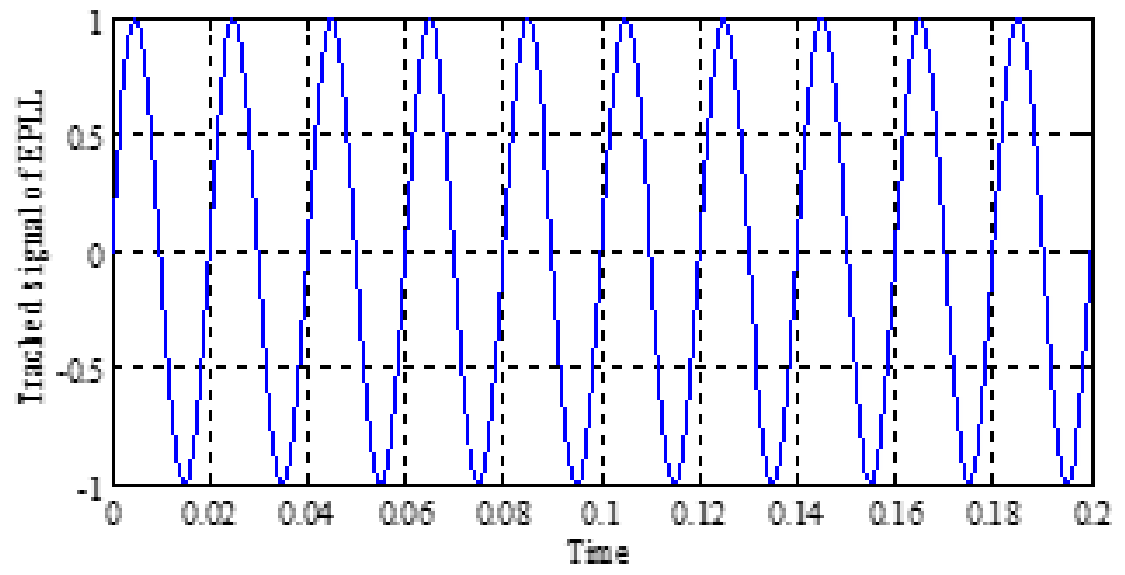

Fig 19. Unit sin vector generated by EPLL

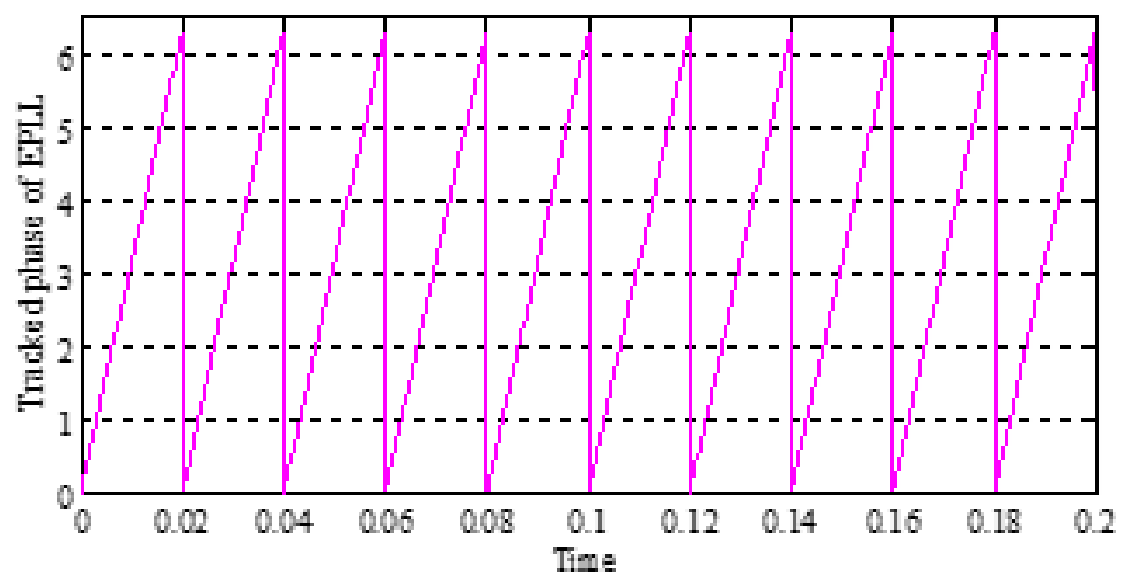

Fig 20. EPLL Tracked phase response 


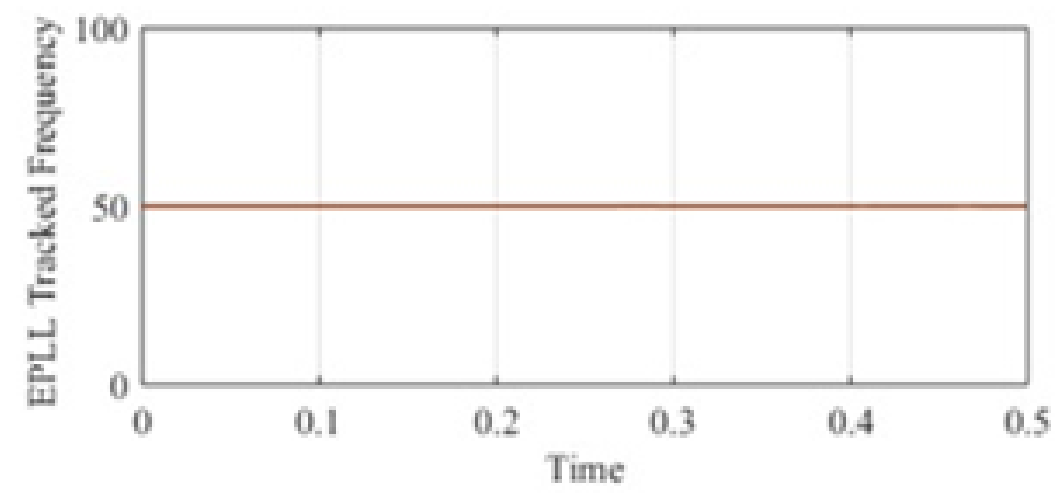

Fig 21. EPLL Tracked frequency

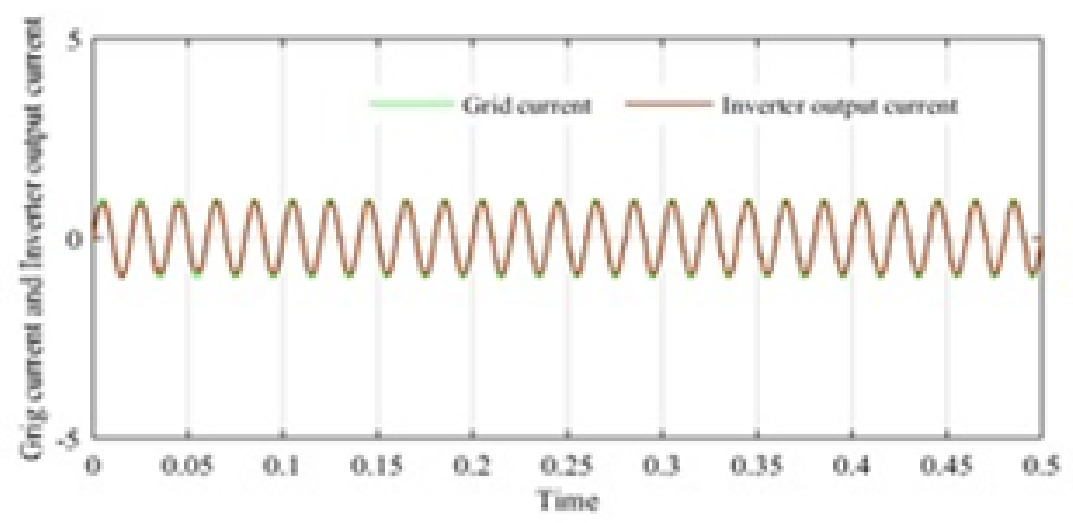

Fig 22. Grid current and Inverter output current signal

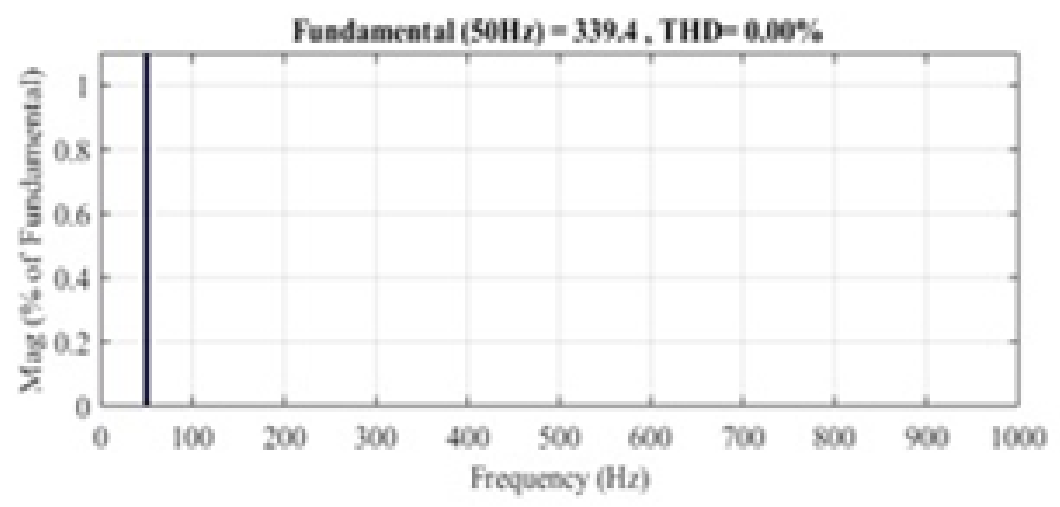

Fig 23. Harmonic spectrum bar graph of the filter output voltage 


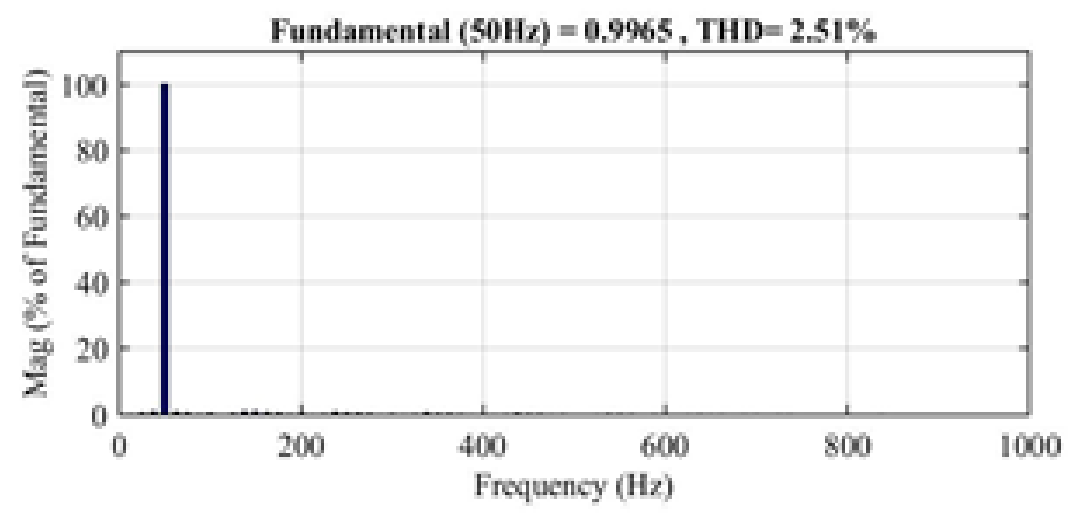

Fig 24. harmonic spectrum bar graph of inverter output current with PLL

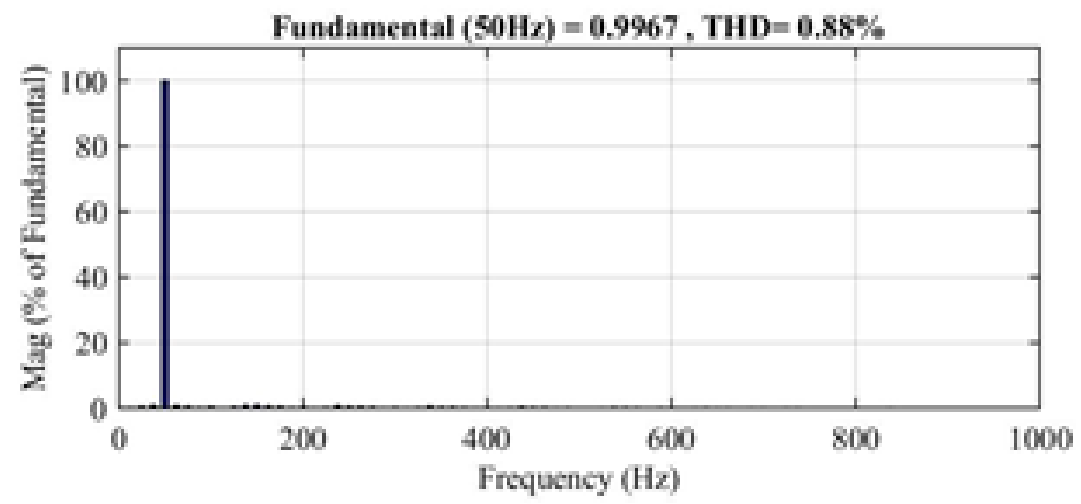

Fig 25. harmonic spectrum bar graph of inverter output current with proposed EPLL

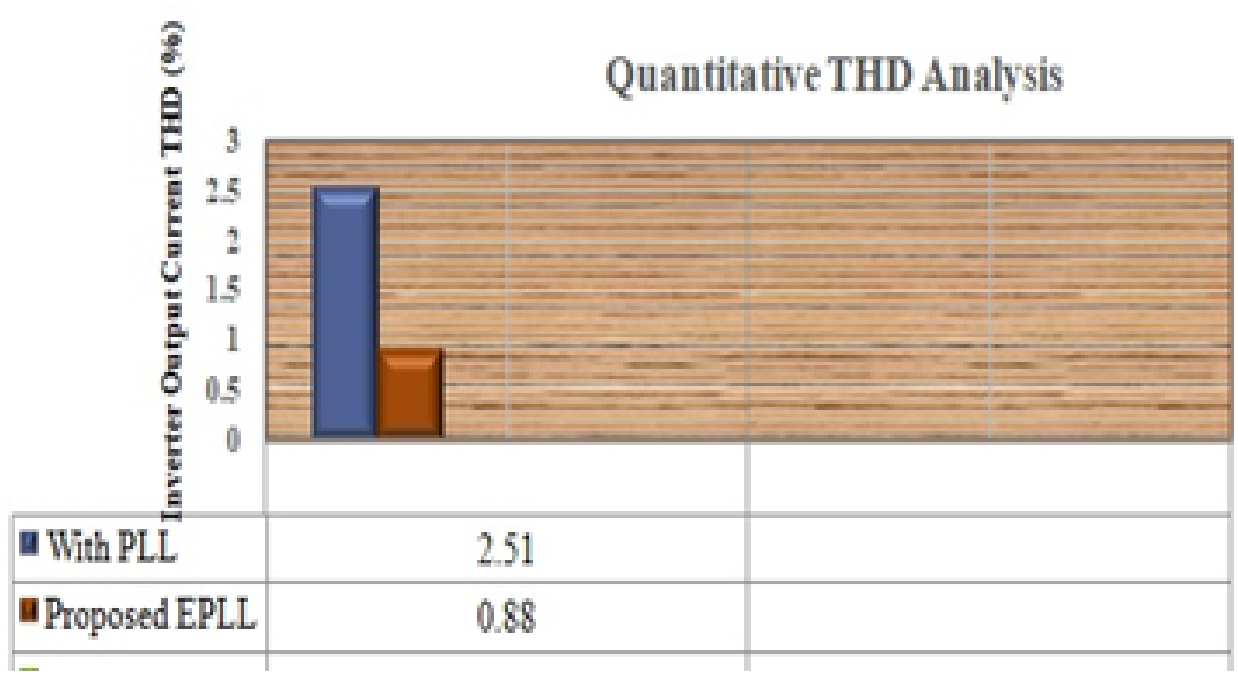

Fig 26. Comparative graphical representation of inverter output current \% THD 


\section{Conclusion}

In the MATLAB 2015(a) environment, the proposed system assembly is modeled and simulated. As MPPT, the INC system has been applied with a boost converter, and the effect on PV panel performance improvement has been shown. The hysteresis band current controller has controlled the PWM inverter current, and the reference current is generated by synchronizing the enhanced phase-locked loop (EPLL). The inverted output current is perfectly synchronized with the grid current, verifying the control efficiency and synchronized scheme based on EPLL. The comparative analysis graph shows that the percent THD performance index parameter of the inverter output current with the proposed EPLL is lower than the traditional PLL. It has been shown by FFT spectral analysis that achieves filtered output voltage is ripple-free pure AC sine wave with zero total harmonic distortion corresponding to the fundamental frequency.

\section{References}

1) Pali BS, Vadhera S. Renewable energy systems for generating electric power: A review. In: IEEE 1st International Conference on Power Electronics, Intelligent Control and Energy Systems (ICPEICES). 2016;p. 1-6. Available from: https://doi.org/10.1109/ICPEICES.2016.7853703.

2) Midilli A, Dincer I, Ay M. Green energy strategies for sustainable development. Energy Policy. 2006;34(18):3623-3633. Available from: https: //dx.doi.org/10.1016/j.enpol.2005.08.003.

3) Villalva MG, Gazoli JR, Filho ER. Comprehensive Approach to Modeling and Simulation of Photovoltaic Arrays. IEEE Transactions on Power Electronics. 2009;24(5):1198-1208. Available from: https://dx.doi.org/10.1109/tpel.2009.2013862.

4) Podder AK, Roy NK, Pota HR. MPPT methods for solar PV systems: a critical review based on tracking nature. IET Renewable Power Generation. 2019;13(10):1615-1632. Available from: https://dx.doi.org/10.1049/iet-rpg.2018.5946.

5) Algarín CR, Giraldo JT, Alvarez OR. Fuzzy Logic Based MPPT Controller for a PV System. Energies. 2017;10(12). Available from: https://dx.doi.org/10. 3390/en10122036.

6) Padullés J, Ault GW, McDonald JR. An integrated SOFC plant dynamic model for power systems simulation. Journal of Power Sources. 2000;86(1-2):495500. Available from: https://dx.doi.org/10.1016/s0378-7753(99)00430-9.

7) Li YH, Rajakaruna S, Choi SS. Control of a Solid Oxide Fuel Cell Power Plant in a Grid-Connected System. IEEE Transactions on Energy Conversion. 2007;22(2):405-413. Available from: https://dx.doi.org/10.1109/tec.2005.853756.

8) Akinyele D, Olabode E, Amole A. Review of fuel cell technologies and applications for sustainable microgrid systems. Inventions;5(42). Available from: https://doi.org/10.3390/inventions5030042.

9) Karimi G, Masoud K, Ali S, Jain PK. Bakhshai Alireza Derivation and design of in-loop filters in phase-locked loop systems. IEEE Transactions on Instrumentation and Measurement. 2012;61(4):930-940. Available from: https://doi.org/10.1109/TIM.2011.2172999.

10) Agrawal S, Palwalia DK, Kumar M. Performance Analysis of ANN Based three-phase four-wire Shunt Active Power Filter for Harmonic Mitigation under Distorted Supply Voltage Conditions. IETE Journal of Research. 2019;p. 1-9. Available from: https://dx.doi.org/10.1080/03772063.2019.1617198.

11) Agrawal S, Palwalia DK. A Modernistic PLL based on feed forward frequency estimator with selective harmonic pre filter for grid imperfection. Internatinal Journal Power and Energy Conversion. 2019;10(3). Available from: https://doi.org/10.1504/IJPEC.2019.102274.

12) Agrawal S, Nagar YK, Palwalia DK. Analysis and implementation of shunt active power filter based on synchronizing enhanced PLL. In: and others, editor. International Conference on Information, Communication, Instrumentation and Control (ICICIC). 2017;p. 1-5. Available from: https: //doi.org/10.1109/ICOMICON.2017.8279152.

13) Kale M, Ozdemir E. An adaptive hysteresis band current controller for shunt active power filter. Electric Power Systems Research. 2005;73:113-119. Available from: https://dx.doi.org/10.1016/j.epsr.2004.06.006.

14) Hojabri M, Ahmad1 AZ, Toudeshki A, Soheilirad M. An overview on current control techniques for grid connected renewable energy systems. In: 2nd International Conference on Power and Energy Systems (ICPES). 2012;p. 119-126. Available from: https://doi.org/10.7763/IPCSIT.2012.V56.22.

15) Kapoor G, Gautam N, Jayaswal K, Tripathi S. Protection of series capacitor compensated double circuit transmission line using wavelet transform. In: IEEE 5th International Conference for Convergence in Technology (I2CT). 2019;p. 1-8. Available from: https://doi.org/10.1109/I2CT45611.2019.9033583.

16) Kumar HBS, Prakash. Panda Babita Modeling and simulation of grid connected hybrid energy system and its fault analysis. International Journal of Power Electronics and Drive Systems. 2018;9(2):775-783. Available from: https://doi.org/10.11591/ijpeds.v9.i2.pp775-783.

17) Kapoor G, Tripathi S, Jain G. Detection of fault and identification of faulty phase in series capacitor compensated transmission line using wavelet transform. In: IEEE 5th International Conference for Convergence in Technology (I2CT). 2019;p. 1-8. Available from: https://doi.org/10.1109/I2CT45611.2019. 9033807.

18) Dahona PA, Krisbiantoro I. A hysteresis current controller for single phase full bridge inverters. In: and others, editor. IEEE 4th International Conference on Power Electronics and Drive Systems (PEDS). 2001;p. 414-419. Available from: https://doi.org/10.1109/PEDS.2001.975349.

19) Agrawal S, Seemant C, Palwalia DK. Hybrid energy management system design with renewable energy sources (Fuel Cells. PV Cells and Wind Energy): A Review IJSET. 2018;6(3):174-177.

20) Agrawal S, Palwalia DK. Analysis of standalone hybrid PV-SOFC-battery generation system based on shunt hybrid active power filter for harmonics mitigation. In: and others, editor. IEEE 7th Power India International Conference (PIICON). 2016;p. 1-6. Available from: https://doi.org/10.1109/ POWERI.2016.8077229.

21) Rezk H, Kanagaraj N, Al-Dhaifallah M. Design and Sensitivity Analysis of Hybrid Photovoltaic-Fuel-Cell-Battery System to Supply a Small Community at Saudi NEOM City. Sustainability. 2020;12(8). Available from: https://dx.doi.org/10.3390/su12083341. 